
МОЗ України

\title{
ОСОБЛИВОСТІ ДОБОВОГО РИТМУ АРТЕРІАЛЬНОГО ТИСКУ У ДІТЕЙ ІЗ ВАЗОВАГАЛЬНИМИ СИНКОПЕ
}

\begin{abstract}
Мета дослідження - визначити особливості добового ритму артеріального тиску у дітей із вазовагальними синкопе за допомогою методу добового моніторування артеріального тиску.

Матеріали та методи. Основну групу склали 65 дітей віком 8-17 років із діагнозом вазовагального синкопе. До контрольної групи увійшла 41 здорова дитина аналогічного віку без ознак гострих чи хронічних захворювань. Для діагностики вазовагальних синкопе використовували критерії Європейської асоціації кардіологів 2018 р. Усім обстеженим проводили добовий моніторинг артеріального тиску за допомогою осцилометричного монітора ВАТ41-2 (Україна) протягом 24 год за умов звичайного фрункціонування.

Результати дослідження та їх обговорення. Діти двох груп були зіставними за результатами демограсічних та клінічних показників, що дозволило нівелювати вплив статі, віку, десріциту та надлишкової маси тіла й ожиріння на показники артеріального тиску. Жодних відмінностей у поширеності денної та нічної систолічної й діастолічної гіпертензії у дітей двох груп не реєстрували. Варіабельність артеріального тиску не змінювалася залежно від наявності як мінімум одного епізоду вазовагального синкопе в анамнезі впродовж останнього місяця. Гіпертензію «білого халата» діагностували у 10 $(15,4 \%)$ хворих із вазовагальними синкопе порівняно 31 (2,4 \%) дитиною в групі контролю (p=0,0333). Аналіз циркадних ритмів показав, що у групі вазовагальних синкопе оптимальне нічне зниження артеріального тиску (dippers) було у 46,2 \% пацієнтів за профрілем систолічного артеріального тиску та у 60,0 \% за профрілем діастолічного артеріального тиску. У 47,7 \% обстежених виявляли патологічний тип із недостатнім (non-dippers) зниженням нічного систолічного артеріального тиску, що було достовірно вищим порівняно з контрольною групою $(p=0,0078)$.

Висновки. Добові, денні та нічні профрілі систолічного, діастолічного, середнього та пульсового артеріального тиску в пацієнтів із вазовагальними синкопе та у здорових дітей не відрізняються. Гіпертензія «білого халата» частіше діагностується у хворих із вазовагальними синкопе порівняно зі здоровими респондентами та може свідчити про їх знижену стресостійкість. Поширеність патологічного профрілю «non-dippers» нічного зниження систолічного артеріального тиску становить 47,7 \% та є обґрунтуванням диссункції автономної нервової системи у дітей із вазовагальними синкопе.
\end{abstract}

Ключові слова: вазовагальні синкопе; добовий моніторинг артеріального тиску; гіпертензія «білого халата»; діти.

ОСОБЕННОСТИ СУТОЧНОГО РИТМА АРТЕРИАЛЬНОГО ДАВЛЕНИЯ У ДЕТЕЙ С ВАЗОВАГАЛЬНЫМИ СИНКОПЕ

Цель исследования - определить особенности суточного ритма артериального давления у детей с вазовагальными обмороками с помощью метода суточного мониторирования артериального давления.

Материалы и методы. Основную группу составили 65 детей в возрасте 8-17 лет с диагнозом вазовагального обморока. В контрольную группу вошел 41 здоровый ребенок аналогичного возраста без признаков острых или хронических заболеваний. Для диагностики вазовагальных обмороков использовали критерии Европейской ассоциации кардиологов 2018 года. Всем обследованным проводили суточный мониторинг артериального давления с помощью осциллометрического монитора ВАТ41-2 (Украина) в течение 24 ч в условиях нормального фрункционирования.

Результаты исследования и их обсуждение. Дети двух групп были сопоставимы по результатам демограсрических и клинических показателей, что позволило нивелировать влияние пола, возраста, дефицита и избыточной массы тела и ожирения на показатели артериального давления. Никаких различий в распространенности дневной и ночной систолической и диастолической гипертензии у детей двух групп не регистрировали. Вариабельность артериального давления не менялась в зависимости от наличия как минимум одного эпизода вазовагального обморока в анамнезе в течение последнего месяца. Гипертензию «белого халата» диагностировали у 10 (15,4 \%) больных с вазовагальными обмороками по сравнению с 1 $(2,4 \%)$ ребенком в группе контроля $(\mathrm{p}=0,0333)$. Анализ циркадных ритмов показал, что в группе вазовагальных синкопе оптимальное ночное снижение артериального давления (dippers) было в 46,2 \% пациентов по профилю систолического артериального давления и в 60,0 \% по профилю диастолического артериального давления. В 47,7 \% обследованных обнаруживали патологический тип с недостаточным (non-dippers) снижением ночного систолического артериального давления, что было достоверно выше по сравнению с контрольной группой ( $p=0,0078)$.

Выводы. Суточные, дневные и ночные профили систолического, диастолического, среднего и пульсового артериального давления у пациентов с вазовагальными синкопе и у здоровых детей не отличаются. Гипертензия «белого халата» чаще диагностируется у больных с вазовагальными синкопе по сравнению со здоровыми респондентами и может свидетельствовать об их пониженной стрессоустойчивости. Распространенность патологического просиля «non-dippers» ночного снижения систолического артериального давления составляет 47,7 \% и является обоснованием диссункции вегетативной нервной системы у детей с вазовагальными синкопе.

Ключевые слова: вазовагальные синкопе; суточный мониторинг артериального давления; гипертензия «белого халата»; дети.

THE FEATURES OF THE CIRCADIAN RHYTHM OF BLOOD PRESSURE IN CHILDREN WITH VASOVAGAL SYNCOPE

The aim of the study - to determine the features of the circadian rhythm of blood pressure in children with vasovagal syncope using the method of ambulatory blood pressure monitoring. 
Materials and Methods. The main group consisted of 65 children aged 8-17 years with a diagnosis of vasovagal syncope. The control group included 41 healthy children of the same age without signs of acute or chronic diseases. The criteria of the European Association of Cardiologists 2018 were used for diagnosing of vasovagal syncope. All surveys conducted ambulatory blood pressure monitoring using an oscillometric monitor VAT41-2 (Ukraine) for 24 hours under normal daily functioning.

Results and Discussion. Children of two groups were comparable in terms of demographic and clinical indicators, which helped to reduce the impact of gender, age, underweight, overweight, and obesity on blood pressure. No differences in the prevalence of day and night systolic and diastolic hypertension in children of two groups were registered. Blood pressure variability did not change depending on the presence of at least one episode of vasovagal syncope in the anamnesis during the last month. White coat hypertension was diagnosed in $10(15.4 \%)$ patients with vasovagal syncope compared with $1(2.4 \%)$ child in the control group $(p=0.0333)$. Analysis of circadian rhythms showed that in the group of vasovagal syncope, the optimal nocturnal fall in blood pressure (dippers) was in $46.2 \%$ of patients for systolic blood pressure and $60.0 \%$ for diastolic blood pressure. In $47.7 \%$ of subjects was found non-dippers type of nocturnal systolic blood pressure fall, which was significantly higher compared to the control group $(p=0.0078)$.

Conclusions. The 24-hours, day and night profiles of systolic, diastolic, mean and pulse blood pressure in patients with vasovagal syncope and in healthy children do not differ. White coat hypertension is more commonly diagnosed in patients with vasovagal syncope than in healthy respondents and may indicate reduced stress resistance. The prevalence of the non-dippers nocturnal systolic blood pressure fall is $47.7 \%$ and is evidence of the autonomic dysfunction in children with vasovagal syncope.

Key words: vasovagal syncope; ambulatory blood pressure monitoring; white coat hypertension; children.

встУп. Європейська асоціація кардіологів визначає синкопе як транзиторну втрату свідомості внаслідок церебральної гіпоперфузії, що характеризується швидким початком, короткою тривалістю та повним спонтанним одужанням [1]. Вважається, що вегетативна нервова система та біологічні фрактори відіграють ключову роль у патогенезі вазовагальних синкопе (ВВС) [2-4]. Контроль артеріального тиску (АТ) та адекватна перфузія внутрішніх органів $€$ життєво важливим завданням вегетативної нервової системи. Механізми фрізіологічного зворотного зв'язку регулюють та підтримують АТ на належному рівні залежно від положення тіла та інших чинників через барорефрлексні петлі краніо-сакральних парасимпатичних та торако-люмбальних симпатичних нейронних шляхів [5, 6]

На сьогодні добре відомо, що майже всі функції серцево-судинної системи зумовлені циркадними коливаннями частоти серцевих скорочень (ЧСС) та АТ як у хворих, так і здорових осіб $[7,8]$. В одному з досліджень було показано, що частота епізодів ВВС у дітей найвища в ранковий час доби та в середині тижня, а найнижча у вихідні дні [9]. Спостерігаються статистичні відмінності в циркадному ритмі синкопальних епізодів щодо статі та віку. Так, синкопальні епізоди в ранкові години частіше виникають у осіб чоловічої статі, а ввечері - у представниць жіночої статі. До того ж, чим менший вік пацієнтів, тим більше шансів розвитку непритомності вранці [10] Цікавим $є$ той фракт, що пацієнти з порушеним нічним сном мають підвищений ризик розвитку синкопе через вплив постуральних стресорів впродовж біологічної ночі [11]. Попри останні наукові досягнення з вивчення даної проблематики, залишається все ще відносно мало відомостей щодо добових коливань регуляції вегетативної нервової системи у пацієнтів із ВВС.

МЕТА ДОСЛІДЖЕННЯ - ВИЗНачитИ особливості ДОбового ритму АТ у дітей із ВBC за допомогою методу добового моніторування артеріального тиску (ДМАТ).

МАТЕРІАЛИ ТА МЕТОДИ. ОСНовну грУПУ склали 65 дітей віком 8-17 років із діагнозом вазовагального синкопе (ВВС). Для діагностики ВВС використовували діагностичні критерії Європейської асоціації кардіологів (2018) [1]. Критерії включення: 1) не менше одного епізоду ВВС впродовж останнього місяця; 2) нормальна реакція на тест активного ортостазу [12]; 3) відсутність структурних захворювань серця та даних електрокардіографрії, що свідчать про аритмогенний ґенез синкопе; 4) відсутність на електроенцефалографії ознак епілептиформної активності головного мозку; 5) відсутність будь-якої іншої очевидної етіології синкопе; 6) відсутність супутніх хронічних або гострих захворювань; 7) відсутність напередодні та під час обстеження приймання будь-яких препаратів, які підвищують або знижують АТ.

У дітей із групи ВВС ретельно збирали скарги та анамнез хвороби - вік на момент першої втрати свідомості; срактори, які передували первинному синкопе; частота, періодичність, стереотипність та серійність нападів; тригерні фрактори; методи, які дозволяють попередити втрату свідомості; клінічні прояви в пресинкопальному періоді; симптоми під час втрати свідомості; клінічні прояви в постсинкопальному періоді; параепілептичні феномени; спадкові фрактори. Для діагностики ВВС у дітей та їх диференційної діагностики з епілепсією використовували Calgary Syncope Seizure Score i Modified Calgary Syncope Seizure Score [13]. Усі діти із ВВС були оглянуті окулістом, неврологом та кардіологом.

До групи порівняння увійшла 41 практично здорова дитина аналогічного віку, яка не мала скарг, анамнестичних даних та клінічних ознак, що свідчили б про наявність будь-якого гострого чи хронічного захворювання. Демограсрічні та клінічні показники обстежених груп пацієнтів представлено у таблиці 1.

У всіх обстежених дітей чсС визначали в положенні сидячи після перебування у стані спокою не менше 5 хв. Офрісний АТ визначали аускультативним методом згідно з чинними рекомендаціями Європейського товариства гіпертензії 2016 року [14]. Після перебування пацієнта у спокої впродовж 5 хв АТ вимірювали в положенні сидячи тричі з інтервалом у 3 хв на двох руках. За результат приймали середнє значення з останніх двох вимірювань на тій руці, де АТ був вищий.

Середній артеріальний тиск (СрАТ, мм рт. ст.) визначали за фрормулою:

$$
\text { СрАТ = ДАТ + (САТ-ДАТ }) / 3,
$$

де ДАТ - діастолічний артеріальний тиск, мм рт. ст.; САТ - систолічний артеріальний тиск, мм рт. ст. 
Пульсовий артеріальний тиск (ПАТ, мм рт. ст.) обчислювали за фрормулою:

$$
\text { ПАТ = САТ }- \text { ДАТ, }
$$

де САТ - систолічний артеріальний тиск, мм рт. ст.; ДАТ - діастолічний артеріальний тиск, мм рт. ст.

ДМАТ проводили за допомогою осцилометричного монітора ВАТ41-2 (Україна) з використанням манжети відповідного розміру протягом 24 год за умов звичайного функціонування. АТ реєстрували на «неробочій» руці, однак у випадку асиметрії більше 10 мм рт. ст. - на руці 3 більшим значенням АТ. Манжету фріксували на плечі на 2 см вище ліктьового згину. Автоматичні вимірювання проводили кожні 15 хвилин протягом дня та кожні 30 хвилин протягом ночі. Денним вважали АТ у період з 07:00 до 21:59, а нічним - у період з 22:00 до 06:59. Кожен пацієнт був інформований про те, що під час вимірювання АТ рука з манжетою повинна бути витягнута уздовж тулуба, повністю нерухома і максимально розслаблена. Якщо визначення АТ починалося під час ходьби, потрібно було зупинитися й опустити руку до завершення вимірювання. У день проведення ДМАТ були виключені усі інтенсивні фрізичні навантаження. Кожен пацієнт вів щоденник, у якому відображав розклад дня, емоційне та розумове навантаження, зміни самопочуття. Результати моніторингу зіставляли з фрізичною активністю пацієнтів, встановлювали наявність порушень нічного сну під час проходження діагностичної процедури. Для інтерпретації показників ДМАТ використовували рекомендації Європейського товариства гіпертензії 2014 року [15].

При аналізі даних, отриманих у ході проведення ДМАТ, оцінювали такі групи параметрів: середні значення АТ (САТ, ДАТ, СрАТ, ПАТ) за добу, день та ніч; варіабельність АТ; нічне зниження АТ; ранкове підвищення АТ (величина і швидкість); показники «навантаження тиском» (індекс часу гіпертензії, індекс площі під грасріком) за добу, день та ніч; індекс резистентності судин; ЧСС за добу, день та ніч. За величиною добового індексу виділяли 4 ступені нічного зниження АТ: оптимальний (dippers) - добовий індекс 10-22 \%; недостатній (non-dippers) - добовий індекс 0-10 \%; підвищений (over-dippers) - добовий індекс понад 22 \%; стійкий підвищений (night-peakers) - добовий індекс менше 0 [16].

Усі респонденти брали участь у дослідженні лише після підписання інформованої згоди дітьми та їх батьками. У роботі дотримано етичних принципів щодо людей, які виступають суб'єктами дослідження, з урахуванням основних положень GCP ICH і Гельсінської декларації Всесвітньої медичної асоціації з біомедичних досліджень, у яких людина виступає їх об'єктом (World Medical Association Declaration of Helsinki, 1964, 2000, 2008), Конвенції Ради Європи про права людини й біомедицину (2007).

Статистичний аналіз отриманих результатів здійснювали за допомогою статистичного пакета програми SPSS 12.0 для Windows. Результати вимірювань представлені як середнє арифрметичне (M) \pm середнє квадратичне відхилення (m). Порівняння між групою ВВС та контрольною групою проводили за допомогою U-критерію Манна-Уїтні. Зіставлення частотних характеристик якісних показників здійснювали з використанням критерію $\chi 2$. Значимість відмінностей брали за вірогідну при р<0,05.

РЕЗУЛЬТАТИ ДОСЛІДЖЕННЯ ТА ЇХ ОБГОВОРЕНня. Діти двох груп були зіставними за результатами демографрічних та клінічних показників, про що свідчать дані таблиці 1. Це дозволило нівелювати вплив статі, віку, десіциту та надлишкової маси тіла й ожиріння на показники АТ в обстежених. Нами не було виявлено жодних відмінностей в офрісному САТ, ДАТ, СрАТ та ПАТ у групі ВВС.

За результатами ДМАТ, денну систолічну артеріальну гіпертензію (АГ) у жодної дитини не спостерігали. Денну діастолічну АГ реєстрували лише у 2 (3,1 \%) дітей із ВВС, що порівняно з контролем було статистично незначимим ( єнтів із групи ВВС супроти 2 (4,9\%) із контрольної групи $(p=0,9432)$, нічну діастолічну АГ - у 4 (6,2\%) супроти 2 $(4,9 \%)$ обстежених відповідно ( $p=0,7819)$.

Циркадний ритм артеріального тиску є однією з найважливіших особливостей людського організму. 3 точки зору нормальної фрізіології, симпатичні нерви переважають у денний час, що підсилює концентрацію катехо-

Таблиця 1. Демографічні та клінічні показники обстежених груп пацієнтів

\begin{tabular}{|c|c|c|c|}
\hline Показник & $\begin{array}{c}\text { Група BBC } \\
(\mathrm{n}=65)\end{array}$ & $\begin{array}{c}\text { Контрольна група } \\
(n=41)\end{array}$ & P \\
\hline Вік, роки & $14,03 \pm 0,27$ & $12,96 \pm 0,42$ & 0,0563 \\
\hline Хлопці/дівчата, n & $37 / 28$ & $17 / 24$ & 0,1210 \\
\hline Вік на момент першого синкопе, роки & $12,9 \pm 0,35$ & & \\
\hline Кількість епізодів синкопе за життя, $\mathrm{n}$ & $3,43 \pm 0,56$ & & \\
\hline Calgary Syncope Seizure Score, бали & $1,74 \pm 0,24$ & & \\
\hline Modified Calgary Syncope Seizure Score, бали & $-2,78 \pm 0,21$ & & \\
\hline $\mathrm{IMT}, \mathrm{\kappa r} / \mathrm{M}^{2}$ & $19,67 \pm 0,41$ & $18,82 \pm 0,38$ & 0,3534 \\
\hline ЧСС, уд/хв & $82,55 \pm 1,31$ & $83,44 \pm 1,31$ & 0,7327 \\
\hline САТ, мм рт. ст. & $112,78 \pm 1,72$ & $113,54 \pm 1,01$ & 0,8517 \\
\hline ДАТ, мм рт. ст. & $68,02 \pm 1,20$ & $68,30 \pm 1,04$ & 0,9543 \\
\hline СрАТ, мм рт. ст. & $81,47 \pm 1,65$ & $82,60 \pm 1,03$ & 0,9948 \\
\hline ПАТ, мм рт. ст. & $44,34 \pm 0,97$ & $46,46 \pm 1,77$ & 0,5323 \\
\hline
\end{tabular}

Примітка. ІМТ - індекс маси тіла; чСС - частота серцевих скорочень; САТ - систолічний артеріальний тиск; ДАТ - діастолічний артеріальний тиск, СрАТ - середній артеріальний тиск, ПАТ - пульсовий артеріальний тиск. У всіх випадках для порівняння двох незалежних вибірок використовували критерій Манна-Уїтні, окрім показника хлопці/дівчата, де застосовували критерій Х2. 
ламінів у плазмі. Вагусний нерв домінує під час нічного сну, а концентрація катехоламінів у крові знижується [17, 18]. Використання неінвазивного ДМАТ дозволяє краще виявити коливання АТ та його циркадний ритм. Більше того, в одному з досліджень було показано, що ДМАТ $€$ значно чутливішим методом діагностики постуральної гіпотензії, ніж тест пасивного ортостазу (тілт-тест) [19].
Визначені за допомогою ДМАТ показники АТ в основній та контрольній групах представлено у таблиці 2. Нами не було знайдено жодних достовірних відмінностей у добовому, денному та нічному САТ, ДАТ, СрАТ і ПАТ у дітей із ВВС порівняно зі здоровими. Варіабельність АТ теж не змінювалася залежно від наявності як мінімум одного епізоду ВВС в анамнезі впродовж останнього місяця. До-

Таблиця 2. Основні показники АТ за даними ДМАТ у дітей із ВВС та контрольній групі

\begin{tabular}{|c|c|c|c|}
\hline Показники & Група ВВС & $\begin{array}{c}\text { Контрольна } \\
\text { група }\end{array}$ & $\mathrm{p}$ \\
\hline Добовий САТ, мм рт. ст. & $108,8 \pm 1,78$ & $110,00 \pm 0,94$ & 0,810051 \\
\hline Добовий ДАТ, мм рт. ст. & $64,77 \pm 0,71$ & $63,98 \pm 0,57$ & 0,558221 \\
\hline Денний САТ, мм рт. ст. & $114,39 \pm 1,01$ & $112,56 \pm 0,99$ & 0,211110 \\
\hline Денний ДАТ, мм рт. ст. & $69,49 \pm 0,77$ & $68,12 \pm 0,63$ & 0,273273 \\
\hline Нічний САТ, мм рт. ст. & $104,57 \pm 1,07$ & $105,49 \pm 1,05$ & 0,563183 \\
\hline Нічний ДАТ, мм рт. ст. & $57,29 \pm 0,73$ & $56,85 \pm 0,76$ & 0,868283 \\
\hline Добовий САТ вище норми, \% & $15,43 \pm 1,85$ & $16,39 \pm 1,99$ & 0,252086 \\
\hline Добовий ДАТ вище норми, \% & $24,50 \pm 1,92$ & $23,05 \pm 1,65$ & 0,917844 \\
\hline Денний АТ вище норми, \% & $8,91 \pm 1,13$ & $10,73 \pm 1,49$ & 0,173731 \\
\hline Денний ДАТ вище норми, \% & $19,53 \pm 1,87$ & $16,02 \pm 1,51$ & 0,456033 \\
\hline Нічний САТ вище норми, \% & $15,32 \pm 2,38$ & $22,05 \pm 3,25$ & $0,031669 *$ \\
\hline Нічний ДАТ вище норми, \% & $19,71 \pm 2,38$ & $19,20 \pm 2,69$ & 0,846340 \\
\hline Добовий СрАТ, мм рт. ст. & $80,06 \pm 0,75$ & $79,27 \pm 0,62$ & 0,576001 \\
\hline Денний СрАТ, мм рт. ст. & $84,38 \pm 0,71$ & $82,78 \pm 0,69$ & 0,167984 \\
\hline Нічний СрАТ, мм рт. ст. & $73,06 \pm 0,79$ & $73,00 \pm 0,71$ & 0,909427 \\
\hline Добовий ПАТ, мм рт. ст. & $45,78 \pm 0,66$ & $46,00 \pm 0,77$ & 0,473848 \\
\hline Денний ПАТ, мм рт. ст. & $44,88 \pm 0,68$ & $44,34 \pm 0,68$ & 0,789508 \\
\hline Нічний ПАТ, мм рт. ст. & $47,29 \pm 0,76$ & $98,80 \pm 1,11$ & 0,146542 \\
\hline Варіабельність АТ для добового САТ, мм рт. ст. & $13,32 \pm 0,43$ & $13,15 \pm 0,47$ & 0,603858 \\
\hline Варіабельність АТ для добового ДАТ, мм рт. ст. & $13,10 \pm 0,35$ & $13,02 \pm 0,32$ & 0,997312 \\
\hline Варіабельність АТ для денного САТ, мм рт. ст. & $13,41 \pm 0,53$ & $14,19 \pm 0,60$ & 0,466332 \\
\hline Варіабельність АТ для денного ДАТ, мм рт. ст. & $12,89 \pm 0,39$ & $13,11 \pm 0,43$ & 0,782479 \\
\hline Варіабельність АТ для нічного САТ, мм рт. ст. & $9,15 \pm 0,49$ & $8,29 \pm 0,42$ & 0,297801 \\
\hline Варіабельність АТ для нічного ДАТ, мм рт. ст. & $8,49 \pm 0,42$ & $7,69 \pm 0,38$ & 0,486842 \\
\hline Нічне зниження САТ, \% & $8,38 \pm 0,59$ & $6,15 \pm 0,62$ & $0,003888^{*}$ \\
\hline Нічне зниження ДАТ, \% & $16,93 \pm 0,80$ & $16,50 \pm 1,14$ & 0,281187 \\
\hline Ранкове підвищення САТ, мм рт. ст. & $30,31 \pm 1,86$ & $30,90 \pm 2,48$ & 0,997410 \\
\hline Ранкове підвищення ДАТ, мм рт. ст. & $30,22 \pm 1,75$ & $33,15 \pm 2,42$ & 0,327045 \\
\hline Швидкість ранкового підвищення САТ, мм рт. ст./хв & $0,82 \pm 0,11$ & $0,80 \pm 0,14$ & 0,927623 \\
\hline Швидкість ранкового підвищення ДАТ, мм рт. ст./хв & $0,81 \pm 0,13$ & $0,74 \pm 0,10$ & 0,516467 \\
\hline Індекс часу гіпертензії для добового САТ, \% & $9,11 \pm 1,38$ & $11,50 \pm 1,73$ & $0,038892^{*}$ \\
\hline Індекс часу гіпертензії для добового ДАТ, \% & $16,38 \pm 1,81$ & $13,77 \pm 1,43$ & 0,683549 \\
\hline Індекс часу гіпертензії для денного САТ, \% & $6,96 \pm 0,99$ & $8,50 \pm 1,36$ & 0,189458 \\
\hline Індекс часу гіпертензії для денного ДАТ, \% & $15,70 \pm 1,80$ & $12,64 \pm 1,31$ & 0,741292 \\
\hline Індекс часу гіпертензії для нічного САТ, \% & $12,75 \pm 2,39$ & $16,97 \pm 3,15$ & 0,144319 \\
\hline Індекс часу гіпертензії для нічного ДАТ, \% & $16,59 \pm 2,26$ & $15,6 \pm 2,64$ & 0,850183 \\
\hline Індекс площі під графіком для добового САТ, мм рт. ст.·год/добу & $0,93 \pm 0,15$ & $1,01 \pm 0,16$ & 0,146460 \\
\hline Індекс площі під графіком для добового ДАТ, мм рт. ст.·год/добу & $1,52 \pm 0,25$ & $0,01 \pm 0,11$ & 0,937876 \\
\hline Індекс площі під графіком для денного САТ, мм рт. ст.·год/добу & $0,81 \pm 0,13$ & $1,00 \pm 0,18$ & 0,173159 \\
\hline Індекс площі під графріком для денного ДАТ, мм рт. ст.·год/добу & $1,54 \pm 0,24$ & $1,05 \pm 0,11$ & 0,943044 \\
\hline Індекс площі під графріком для нічного САТ, мм рт. ст.·год/добу & $1,08 \pm 0,26$ & $0,03 \pm 0,26$ & 0,143816 \\
\hline Індекс площі під графріком для нічного ДАТ, мм рт. ст.·год/добу & $1,32 \pm 0,24$ & $0,35 \pm 0,20$ & 0,857227 \\
\hline Індекс резистентності судин, у. о. & $0,39 \pm 0,03$ & $0,45 \pm 0,03$ & 0,188788 \\
\hline
\end{tabular}

Примітка. САТ - систолічний артеріальний тиск; ДАТ - діастолічний артеріальний тиск; СрАТ - середній артеріальний тиск; ПАТ - пульсовий артеріальний тиск; АТ - артеріальний тиск. Для порівняння двох незалежних вибірок використовували критерій Манна-Уїтні. * - p<0,05 порівняно з контрольною групою. 
бовий профріль АТ в обстежених із ВВС характеризувався меншим відсотком нічного САТ вище норми, більшим відсотком нічного зниження САТ, зниженням відсотка індексу часу гіпертензії для добового САТ.

Наявні до сьогодні дослідження у світовій медичній літературі в даній когорті пацієнтів є досить суперечливими. Так, Onishi Y. та ін. обґрунтували гіперактивність парасимпатичної нервової системи в денний час на підставі зниження САТ та ДАТ у дорослих пацієнтів із ВВС [20]. Погодіна А. В. та ін. довели надмірне нічне зниження ДАТ при ВВС у дітей та припустили, що порушення неврального контролю тонусу судин може бути важливим патофрізіологічним механізмом у формуванні схильності до непритомності даного типу [21]. Разом з тим, група китайських науковців різниці у добових коливаннях АТ у дітей із ВВС порівняно зі здоровими респондентами не виявила [22].

Жодних відмінностей у поширеності надмірного ранкового підвищення АТ виявлено не було - 7,7 \% у групі ВВС та 7,3 \% у контрольній групі ( $p=0,9432)$. Гіпертензію «білого халата» діагностували у 10 (15,4\%) хворих із ВВС порівняно $з 1$ (2,4%) дитиною в групі контролю ( $p=0,0333)$. Офрісний тиск в основній групі склав $(136,8 \pm 3,81)$ мм рт. ст. для САТ та $(93,7 \pm 2,12)$ мм рт. ст. для ДАТ. Європейське товариство гіпертензії (2016) визначає гіпертензію «білого халата» як підвищений АТ у лікарні та нормальний AT поза межами лікувального закладу. До сьогодні не з'ясовано, чи є дане явище варіантом нормальної реакції організму чи передумовою розвитку АГ в майбутньому [14]. Гіпертензія «білого халата» виникає у тих пацієнтів, які реагують на стрес підвищенням АТ. Цілком імовірно, що ці пацієнти також реагують підвищенням АТ на повсякденний стрес [23, 24].

Аналіз циркадних ритмів показав, що у групі ВBC оптимальне нічне зниження АТ (dippers) було у 46,2 \% пацієнтів за профрілем САТ та у 60,0 \% за профрілем ДАТ. Хоча нічне зниження САТ у дітей із ВВС було достовірно вищим порівняно з контролем (табл. 1), у 47,7 \% обстежених виявляли патологічний тип із недостатнім (non-dippers, добовий індекс 0-10\%) зниженням нічного САТ (табл. 3). Отримані результати свідчать про високу поширеність дисфункції автономної нервової системи серед дітей із ВВС $[25,26]$, яка і $є$ однією із причин патологічних постуральних гемодинамічних реакцій 3 подальшим розвитком запаморочення та непритомності внаслідок церебральної гіпоперфузії.

\section{Таблиця 3. Поділ обстежених дітей за циркадним ритмом}

\begin{tabular}{|c|c|c|c|c|c|}
\hline AT & Циркадний індекс & Група ВВС & Контрольна група & $x^{2}$ & $\mathrm{p}$ \\
\hline \multirow[t]{4}{*}{ CAT } & Dippers, n (\%) & $30(46,2)$ & $31(75,6)$ & 8,93 & 0,0028 \\
\hline & Non-dippers, n (\%) & $31(47,7)$ & $9(22,0)$ & 7,09 & 0,0078 \\
\hline & Over-dippers, n (\%) & $0(0)$ & $0(0)$ & - & - \\
\hline & Night-peakers, n (\%) & $4(6,1)$ & $1(2,4)$ & 0,77 & 0,3796 \\
\hline \multirow[t]{4}{*}{ ДАТ } & Dippers, n (\%) & $39(60,0)$ & $28(68,3)$ & 0,74 & 0,3886 \\
\hline & Non-dippers, n (\%) & $7(10,8)$ & $4(9,7)$ & 0,03 & 0,8677 \\
\hline & Over-dippers, n (\%) & $19(29,2)$ & $9(22,0)$ & 0,69 & 0,4077 \\
\hline & Night-peakers, n (\%) & $0(0)$ & $0(0)$ & - & - \\
\hline
\end{tabular}

Примітка. САТ - систолічний артеріальний тиск; ДАТ - діастолічний артеріальний тиск; АТ - артеріальний тиск. Зіставлення частотних характеристик якісних показників проводили з використанням критерію 22 . * - p<0,05 порівняно 3 контрольною групою.

ВИСНОВКИ. 1. За даними ДМАТ, добові, денні та нічні профрілі САТ, ДАТ, СрАТ і ПАТ у пацієнтів із як мінімум одним епізодом ВВС впродовж останнього місяця в анамнезі та у здорових дітей не відрізняються.

2. Гіпертензія «білого халата» достовірно частіше діагностується у хворих із ВВС порівняно зі здоровими респондентами та може свідчити про їх знижену стресостійкість.

3. Поширеність патологічного профрілю «non-dippers» нічного зниження САТ становить $47,7 \%$ у групі ВВС та $є$

\section{СПИСОК ЛІТЕРАТУРИ}

1. ESC Guidelines for the diagnosis and management of syncope / M. Brignole, A. Moya, F. J. Lange [et al.] // European Heart Journal. - 2018. - Vol. 39, No. 21. - P. 1883-1948.

2. Kovalchuk T. A. Vitamin D status in patients with nontraumatic transient loss of consciousness (literature review) / T. A. Kovalchuk, O. R. Boyarchuk // Bol', sustavy, pozvonočnik. - 2019. - Vol. 9, No. 3. - P. 178-183. обґрунтуванням дисорункції автономної нервової системи у цих пацієнтів.

ПЕРСПЕКТИВИ ПОДАЛЬШИХ ДОСЛІДЖЕНЬ ПОлягають у поглибленому порівняльному аналізі добового профрілю АТ у дітей різного віку із синкопе вазовагального, ортостатичного та кардіогенного генезу з метою кращого розуміння патогенетичних механізмів розвитку транзиторних втрат свідомості нетравматичного походження та розроблення на підставі отриманих результатів досліджень адекватних лікувально-профрілактичних заходів із модиорікацією показників АТ.

3. Role of the sympathetic nervous system in vasovagal syncope and rationale for beta-blockers and norepinephrine transporter inhibitors supplements / M. F. Márquez, J. R. GómezFlores, J. A. González-Hermosillo [et al.] // Medwave. - 2016. - Vol. 16, No. 4. -e6824

4. Pubertal hormonal changes and the autonomic nervous system: potential role in pediatric orthostatic intolerance / 
K. E. Coupal, N. D. Heeney, B. C. D. Hockin [et al.] // Front Neurosci. - 2019. - No. 13. - P. 1197.

5. Twenty-four hour non-invasive ambulatory blood pressure and heart rate monitoring in Parkinson's disease / E. Stuebner, E. Vichayanrat, D. A. Low [et al.] // Frontiers in Neurology. 2013. - No. 4. - P. 49.

6. Kellerova E. Variability and reactive changes of the peripheral blood flow, blood pressure and of the electrical behavior of the heart / E. Kellerova // Act. Nerv. Super Rediviva. - 2013. - Vol. 55, No. 3. - P. 113-124

7. High prevalence of orthostatic dysregulation among circadian rhythm disorder patients / A. Tsuchiya, T. Kitajima, S. Tomita [et al.] // Journal of Clinical Sleep Medicine. - 2016. - Vol. 12, No. 11. - P. 1471-1476.

8. Serin Y. Effect of circadian rhythm on metabolic processes and the regulation of energy balance / Y. Serin, N. Acar Tek // Ann. Nutr. Metab. - 2019. - No. 74. - P. 322-330.

9. Circadian and infradian rhythms of vasovagal syncope in young and middle-aged subjects / M. Zoghi, H. Duygu, H. Gungor [et al.] // PACE. - 2008. - Vol. 31, No. 12. - P. 1581-1584.

10. The circadian rhythm of syncopal episodes in patients with neurally mediated syncope / D. Liao, Y. Xu, R. Zou [et al.] // International Journal of Cardiology. - 2016. - No. 215. P. 186-192.

11. Endogenous circadian rhythm in vasovagal response to head-up tilt / K. Hu, F. A Scheer, M. Laker [et al.] // Circulation. - 2011. - Vol. 123, No. 9. - P. 961-970.

12. Japanese clinical guidelines for juvenile orthostatic dysregulation version $1 / \mathrm{H}$. Tanaka, Y. Fujita, Y. Takenaka [et al.] // Pediatr. Int. - 2009. - No. 51. - P. 169-179.

13. Calgary score and modified Calgary score in the differential diagnosis between neurally mediated syncope and epilepsy in children / R. Zou, S. Wang, L. Zhu [et al.] // Neurol. Sci. - 2017. - Vol. 38, No. 1. - P. 143-149.

14. 2016 European Society of Hypertension guidelines for the management of high blood pressure in children and adolescents / E. Lurbea, E. Agabiti-Roseic, J. K. Cruickshank [et al.] // Journal of Hypertension. - 2016. - Vol. 34, No. 1. - P. 1-34.

15. European Society of Hypertension practice guidelines for ambulatory blood pressure monitoring / G. Parati, G. Stergiou, E. O'Brien [et al.] // J. Hypertens. - 2014. - Vol. 32, No. 7. P. 1359-1366.

\section{REFERENCES}

1. Brignole, M., Moya, A., J de Lange, F., Deharo, J.C., Elliott, P.M., Fanciulli A., ..., \& van Dijk J.G. (2018). ESC Guidelines for the diagnosis and management of syncope. European Heart Journal., 39, 21, 1883-1948.

2. Kovalchuk, T.A., \& Boyarchuk, O.R. (2019). Vitamin $D$ status in patients with nontraumatic transient loss of consciousness (literature review). Bol', sustavy, pozvonočnik, 9, 3, 178-183.

3. Márquez, M.F., Gómez-Flores, J.R., González-Hermosillo, J.A, Ruíz-Siller, T.J., Cárdenas, M. (2016). Role of the sympathetic nervous system in vasovagal syncope and rationale for beta-blockers and norepinephrine transporter inhibitors supplements. Medwave, 16, 4, e6824

4. Coupal, K.E., Heeney, N.D., Hockin, B.C.D., Ronsley R., Armstrong, K., Sanatani S., \& Claydon V.E. (2019). Pubertal hormonal changes and the autonomic nervous system: potential role in pediatric orthostatic intolerance. Front Neurosci., 13, 1197.

5. Stuebner, E., Vichayanrat, E., Low, D. A., Mathias, C.J., Isenmann, S., ..., \& Haensch, C.A. (2013). Twenty-four hour non-
16. Dadlani A. Ambulatory blood pressure monitoring in clinical practice / A. Dadlani, K. Madan, J. P. S. Sawhney // Indian Heart Journal. - 2019. - Vol. 71, No. 1. - P. 91-97.

17. Nishihara M. Effect of sympathetic nervous system on circadian rhythm of blood pressure / M. Nishihara, Y. Hirooka // Japanese Journal of Clinical Medicine. - 2014. - Vol. 72, No. 8. - P. 1374-1378.

18. Ambulatory blood pressure monitoring in children suffering from orthostatic hypertension / Y. Zhixiang, W. Cheng, $X$. Jibing [et al.] // Biomedical Engineering Online. - 2018. Vol. 17, No. 1. - P. 129.

19. Usefulness of ambulatory blood pressure monitoring and head-up tilt test in the evaluation of paediatric syncope / U. Giordano, R. Meta, D. Fintini [et al.] // Cardiol. Young. - 2011. - Vol. 21, No. 1. - P. 89-93.

20. Daily dysfunction of autonomic regulation based on ambulatory blood pressure monitoring in patients with neurally mediated reflex syncope / Y. Onishi, Y. Minoura, Y. Chiba [et al.] // PACE. - 2015. - Vol. 38, No. 8. - P. 997-1004.

21. Погодина А. В. Особенности суточного профриля артериального давления у детей и подростков с нейрокардиогенными синкопе / А. В. Погодина, В.В.Долгих, О. В. Валявская // Acta Biomedica Scientifica. - 2011. № 5. - С. 94-98.

22. Ambulatory blood pressure in children with neurally mediated syncope / L. Chen, J. J. Chen, H. F. Jin [et al.] // Beijing Da Xue Xue Bao Yi Xue Ban. - 2009. - Vol. 18, No. 41(3). - P. 343-347.

23. Update: ambulatory blood pressure monitoring in children and adolescents: a scientific statement from the American Heart Association / J. T. Flynn, S. R. Daniels, L. L. Hayman [et al.] // Hypertension. - 2014. - Vol. 63, No. 5. - P. 1116-1135.

24. White coat hypertension in pediatrics / A. Jurko, M. Minarik, T. Jurko, I. Tonhajzerova // Italian Journal of Pediatrics. - 2016. - No. 42. - P. 4.

25. Autonomic Dysfunction in Cardiology: Pathophysiology, Investigation, and Management / A. C. Arnold, J. Ng, L. Lei, S. R. Raj // The Canadian Journal of Cardiology. - 2017. Vol. 33, No. 12. - P. 1524-1534.

26. Dipping in ambulatory blood pressure monitoring correlates with overnight urinary excretion of catecholamines and sodium / R. Darr, M. Bursztyn, C. Pamporaki [et al.] // J. Clin. Hypertens. (Greenwich). - 2016. - Vol. 18. - No. 9. - P. 921-926.

invasive ambulatory blood pressure and heart rate monitoring in Parkinson's disease. Frontiers in Neurology, 4, 49.

6. Kellerova, E. (2013). Variability and reactive changes of the peripheral blood flow, blood pressure and of the electrical behavior of the heart. Act. Nerv. Super Rediviva, 55, 3, 113-124.

7. Tsuchiya, A., Kitajima, T., Tomita, S., Esaki, Y., Hirose, M., ..., \& Iwata, N. (2016). High prevalence of orthostatic dysregulation among circadian rhythm disorder patients. Journal of Clinical Sleep Medicine, 12, 11, 1471-1476.

8. Serin, Y., \&b Acar, T.N. (2019). Effect of circadian rhythm on metabolic processes and the regulation of energy balance. Ann. Nutr. Metab., 74, 322-330.

9. Zoghi, M., Duygu, H., Gungor, H., Nalbantgil, S., Ozerkan, F., Akilli, A., \& Akin, M. Circadian and infradian rhythms of vasovagal syncope in young and middle-aged subjects. PACE, $31,12,1581-1584$

10. Liao, D., Xu, Y., Zou, R., Wu, L., Luo, X., Li., F., ..., \& Wang, C. (2016). The circadian rhythm of syncopal episodes in patients with neurally mediated syncope. International Journal of Cardiology, 215, 186-192. 
11. Hu, K., Scheer, F.A., Laker, M., Smales, C., Shea, S.A. (2011). Endogenous circadian rhythm in vasovagal response to head-up tilt. Circulation, 123, 9, 961-970.

12. Tanaka, H., Fujita, Y., Takenaka, Y., Kajiwara, S., Masutani, S., Ishizaki, Y., ..., \& Task Force of Clinical Guidelines for Child Orthostatic Dysregulation, Japanese Society of Psychosomatic Pediatrics. (2009). Japanese clinical guidelines for juvenile orthostatic dysregulation version 1. Pediatrics International, 51 , 1, 169-179.

13. Zou, R., Wang, S., Zhu, L., Wu, L., Lin, P., Li, F., Xie, Z., Li, X., \& Wang, C. (2017). Calgary score and modified Calgary score in the differential diagnosis between neurally mediated syncope and epilepsy in children. Neurological Sciences, 38 1, 143-149.

14. Lurbe, E., Agabiti-Rosei, E., Cruickshank, J. K., Dominiczak, A., Erdine, S., Hirth, A., ..., \& Zanchetti, A. (2016). 2016 European Society of Hypertension guidelines for the management of high blood pressure in children and adolescents. Journal of Hypertension, 34, 10, 1887-1920.

15. Parati, G., Stergiou, G., O'Brien, E., Asmar, R., Beilin, L., Bilo, G., ..., \& European Society of Hypertension Working Group on Blood Pressure Monitoring and Cardiovascular Variability. (2014). European Society of Hypertension practice guidelines for ambulatory blood pressure monitoring. Journal of Hypertension, 32, 7, 1359-1366.

16. Dadlani, A., Madan, K., \& Sawhney, J.P.S. (2019). Ambulatory blood pressure monitoring in clinical practice. Indian Heart Journal, 71, 1, 91-97.

17. Nishihara, M., \& Hirooka, Y. (2014). Effect of sympathetic nervous system on circadian rhythm of blood pressure. Japanese Journal of Clinical Medicine, 72, 8, 1374-1378.

18. Zhixiang, Y., Cheng, W., Jibing, X., Bisheng, G., Ming, X., \& Deyu, L. (2018). Ambulatory blood pressure monitoring in children suffering from orthostatic hypertension. Biomedical Engineering Online, 17 (1), 129.

19. Giordano, U., Meta, R., Fintini, D., Turchetta, A., Brufani, C., Calzolari, A. (2011). Usefulness of ambulatory blood pressure monitoring and head-up tilt test in the evaluation of paediatric syncope. Cardiol. Young, 21 (1), 89-93.

20. Onishi, Y., Minoura, Y., Chiba, Y., Onuki, T., Ito, H., Adachi, T., ..., \& Kobayashi, Y. (2015). Daily dysfunction of autonomic regulation based on ambulatory blood pressure monitoring in patients with neurally mediated reflex syncope. Pacing and Clinical Electrophysiology: PACE, 38 (8), 997-1004.

21. Pogodina, A.V., Dolgikh, V.V., \& Valyavskaya O.V. (2011). Osobennosty sutochnogo profilta arteryalnogo davleniya $u$ detey i podrostkov s neyrokardiogennymy synkope [Features daily profile of blood pressure in children and adolescents with neurocardiogenic syncope]. Acta Biomedica Scientifica, 5, 9498 [in Russian].

22. Chen, L., Chen, J.J., Jin, H.F., Tang, C.S., \& Du, J.B. (2009). Ambulatory blood pressure in children with neurally mediated syncope. Journal of Peking University. Health Sciences, 41 (3), 343-347.

23. Flynn, J.T., Daniels, S. R., Hayman, L. L., Maahs, D. M., McCrindle, B. W., Mitsnefes, ..., \& American Heart Association Atherosclerosis, Hypertension and Obesity in Youth Committee of the Council on Cardiovascular Disease in the Young (2014). Update: ambulatory blood pressure monitoring in children and adolescents: a scientific statement from the American Heart Association. Hypertension, 63 (5), 1116-1135.

24. Jurko, A., Minarik, M., Jurko, T., \& Tonhajzerova, I. (2016). White coat hypertension in pediatrics. Italian Journal of Pediatrics, 42, 4.

25. Arnold, A.C., Ng, J., Lei, L., \& Raj, S.R. (2017). Autonomic dysfunction in cardiology: Pathophysiology, investigation, and management. The Canadian Journal of Cardiology, 33, 12, 1524-1534.

26. Därr, R., Bursztyn, M., Pamporaki, C., Peitzsch, M., Siegert, G., Bornstein, S. R., Eisenhofer, G. (2016). Dipping in ambulatory blood pressure monitoring correlates with overnight urinary excretion of catecholamines and sodium. Journal of Clinical Hypertension (Greenwich, Conn.), 18 (9), 921-926.

Отримано 08.05.20 Прийнято до друку 11.06.20

Електронна адреса для листування: tetianakovalchuk@gmail.com 